\title{
Vanishing of an isolated population of thick-clawed crayfish Astacus pacbypus (Crustacea: Decapoda: Astacidae) in the Sevastopol Bay (Crimean Peninsula, Black Sea)
}

\author{
Исчезновение изолированной попумящии толстопалого рака \\ Astacus pachypus (Crustacea: Decapoda: Astacidae) \\ в Севастопольской бухте (Крымский полуостров, Черное море)
}

\author{
Sergey E. Anosov*1, Vitaly A. Timofeev ${ }^{2}$ \\ C.Е. Аносов, В.A. Тимофеев
}

\footnotetext{
${ }^{1}$ Russian Federal Institute of Fishery and Oceanography (VNIRO), Verkhnyaya Krasnoselskaya, 17a, Moscow, 107140, Russia.

${ }^{1}$ Всероссийский научно-исследовательский институт рыбного хозяйства и океанографии (ВНИРО), Верхняя Красносельская, д. 17a, Москва 107140, Россия.

${ }^{2}$ A.O. Kowalevsky Institute of Marine Biological research of Russian Academy of Sciences (IMBR RAS), Prospekt Nakhimova, 2 , Sevastopol, 299011, Russia.

${ }^{2}$ Институт морских биологических исследований им. А.О. Ковалевского Российской Академии наук, проспект Нахимова, 2 , Севастополь, 299011, Россия.

* corresponding author; E-mail: florarium@gmail.com

* автор, которому должна быть адресована корреспонденция E-mail: florarium@gmail.com
}

KEY WORDS: Thick-clawed crayfish, endangered species, habitat loss, estuary; Black Sea - Caspian region, Crimea.

КЛЮЧЕВЫЕ СЛОВА: Толстопалый рак, вид, находящийся под угрозой, утрата местообитаний, эстуарий, Черноморско-Каспийский регион, Крым.

ABSTRACT. In the XIX and XX centuries thickclawed crayfish Astacus pachypus was reported for the Sevastopol area in Crimea. Nowadays significant changes of hydrolological conditions and substrates took place in the only possible locality where a population of this species could exist - inner part of the Sevastopol Bay and the mouth of River Chernaya. Biotopes characteristic for this place in the XIX century were lost. Since the conditions optimal for thick-clawed crayfish in the River Chernaya estuary are currently absent, this species most likely has vanished from the Sevastopol area.

РЕЗЮМЕ. В ХІХ и начале ХХ веков в Крыму, в районе Севастополя отмечался толстопалый рак Astacus pachypus. К настоящему времени в месте наиболее вероятного обитания этого вида - кутовой части Севастопольской бухты и устья реки Черной произошли значительные изменения гидрологических условий, субстрата и утрата биотопов, характерных для этих мест в прошлом. Поскольку условия, оптимальные для жизни толстопалого рака в эстуарии реки Черной в настоящее время отсутствуют, то с большой долей вероятности можно предположить, что в районе Севастополя этот вид исчез.

\section{Introduction}

Thick-clawed crayfish (Astacus pachypus Rathke, 1837 ) is a Ponto-Caspian species having a markedly fragmented distribution in the Black. Azov and the Caspian Sea basins (Black Sea - Caspian region). The largest population of this species is located in the Caspian Sea, where it occurs on hard substrates under salinity of 12-14\%o [Cherkashina, 1976]. A. pachypus also occurs at lower salinity in some lagoons, estuaries and in freshwater at the lower reaches of some rivers in the Caspian Sea and the Sea of Azov [Birstein, Vinogradov, 1934; Cherkashina et al., 1996; Souty-Grosset et al., 2006]. In the Black Sea basin thick-clawed crayfish was recorded in the river estuaries of its north-western part, in the lower reaches of such rivers as Bug, Dnieper, Ingul, Ingulets, in the Danube Delta [Rathke, 1837; Souty-Grosset et al., 2006; Mezhzherin et al., 2015], and in the River Devnya in Bulgaria [Bulgurkov, 1964]. It was also reported but not subsequently recorded in Abrau Lake (Krasnodar Region) on the East shore of the Black Sea [Czerniavsky, 1880].

In the past $A$. pachypus showed rather high abundance in particular area and was even fished commercially. In the $1970^{\text {th }}$ thick-clawed crayfish's total allowable catch near the Turkmenian shore of the Caspian Sea was estimated to be 1.8 million specimens [Cherkashina, 1976]. In the River Don, near Starocherkassk (70-80 km from the estuary), its average abundance amounted about to 100 specimens per hectare prior to the 1980s [Cherkashina et al., 1996].

Since the $1980^{\text {th }}$ there were indications of pronounced decline of the species' abundance and its van- 


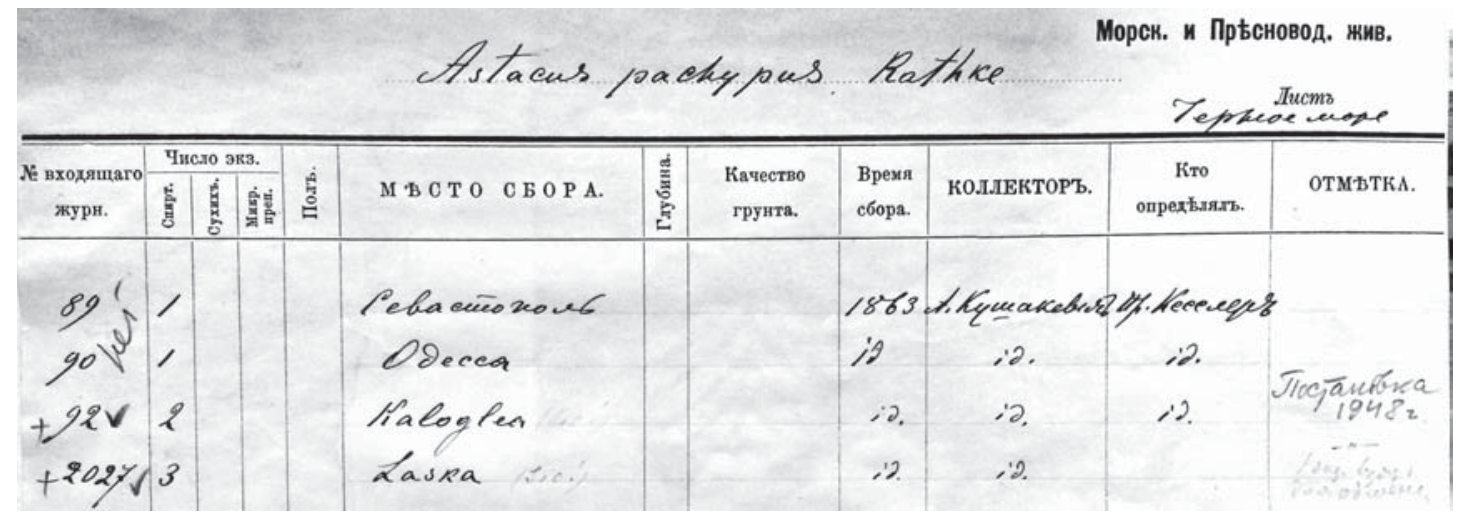

Fig. 1. The card of the catalogue of the Zoological Institute of Russian Academy of Sciences listing historical collections of Astacus pachypus.

Рис. 1. Карточка каталога Зоологического институета РАН с перечислением исторических коллекций Astacus pachypus.

ishing in some areas owing to pollution and habitat loss [Cherkashina et al, 1996; Souty-Grosset et al., 2006; Gherardi, Souty-Grosset, 2010]. In the Ukrainian waters in the north-western part of the Black Sea basin the species nowadays occur extremely seldom [Mezhzherin et al., 2015] while little data exist for the Sea of Azov and the Caspian sea. Local residents of Starocherkassk on Don where the species has been known to be abundant in the past currently communicate it to be rare [Anosov, unpublished observations]. In $2003 \mathrm{~A}$. pachypus was listed in the Rostov Region Red Data Book. Recently it has been included in the IUCN Red List [Gherardi, Souty-Grosset, 2010]. To develop conservation strategy for this species there is an urgent need to document historical changes in species distribution and abundance that remain poorly known.

In the old literature $A$. pachypus was mentioned to occur on the Black Sea coast of Crimean Peninsula in the region of Sevastopol [Kessler 1875; Birstein, Vinogradov, 1934]. This appears to be unusual because of apparent deficiency of characteristic for the species habitats there, i.e. large rivers and extensive brackish areas in the coastal zone. Furthermore, neither scientific nor anecdotal sources of the XX and XXI century confirmed the occurrence of thick-clawed crayfish in Crimea except of Birstein and Vinogradov [1934] who did not provided details and probably based their record on earlier publication by Kessler [Kessler, 1875].

In order to clarify the issue of $A$. pachypus occurrence in Crimea we searched in the historical collections and surveyed the areas which could somehow fit habitat requirement of the species. This communication considers the historical material of thick-clawed crayfish in the Zoological Institute of the Russian Academy of Sciences in St. Petersburg and presents results of surveying the Chernaya River and its estuary, a habitat where the species has been presumably found in the past.

\section{Material and methods}

The collection of Decapoda and the catalogue of the Zoological Institute of the Russian Academy of
Sciences (ZIN RAS) were screened for the Astacus pachypus material.

Possible historical habitats of the species in the inner Sevastopol Bay and the River Chernaya were investigated in August 2015. Water mineralization and $\mathrm{pH}$ were measured using a portable conductometer. Crayfish were searched using direct observations and setting crayfish pots.

\section{Results and discussion}

A single specimen of Astacus pachypus deposited in the Zoological Museum of the Russian Imperial Academy of Sciences, now ZIN RAS (catalogue number 89) was collected in Sevastopol by A. Kuschakevitch in 1863 and identified by K.F. Kessler (Fig. 1). This specimen is not extant in the contemporary collection, the note of its absence in the catalogue (Russian "неm" meaning "no", "absent") has been presumably made after the II World War. However, some other historical collections of the species are extant, in particular an earlier collected specimen with registration number 87 (Astrakhan, K.E. Baer coll., 1859) (Fig. 2). Let us note that currently the species is not reported for the northern Caspian Sea [Souty-Grosset et al., 2006].

As $A$. pachypus is a brackish water species with preference to hard substrates [Cherkashina, 1976] only few localities around Sevastopol match these conditions. These are the estuary of the River Chernaya (Chorgun) and the Lagoon of River Chernaya (Kalamita-Liman), which include the estuary of river and brackish Neftyanaya (Grafskaya). Inlet (Fig. 3, 1-3) which are located in the inner part of Sevastopol Bay.

The conditions of River Chernaya (Biyuk-Uzen) in the middle of XIX century from Chorgun village (Chernorechenskoe) to the lagoon of River Chernaya were described by K.F. Kessler upon the results of his "excursions" undertaken using a fishing boat in 1858 (prior to the collection of the ZIN RAS specimen). He noted: "As in the top of Sevastopol bay, so as in other parts with small depths ... the bottom is covered with a dense meadow of marine grass (Zostera marina et 


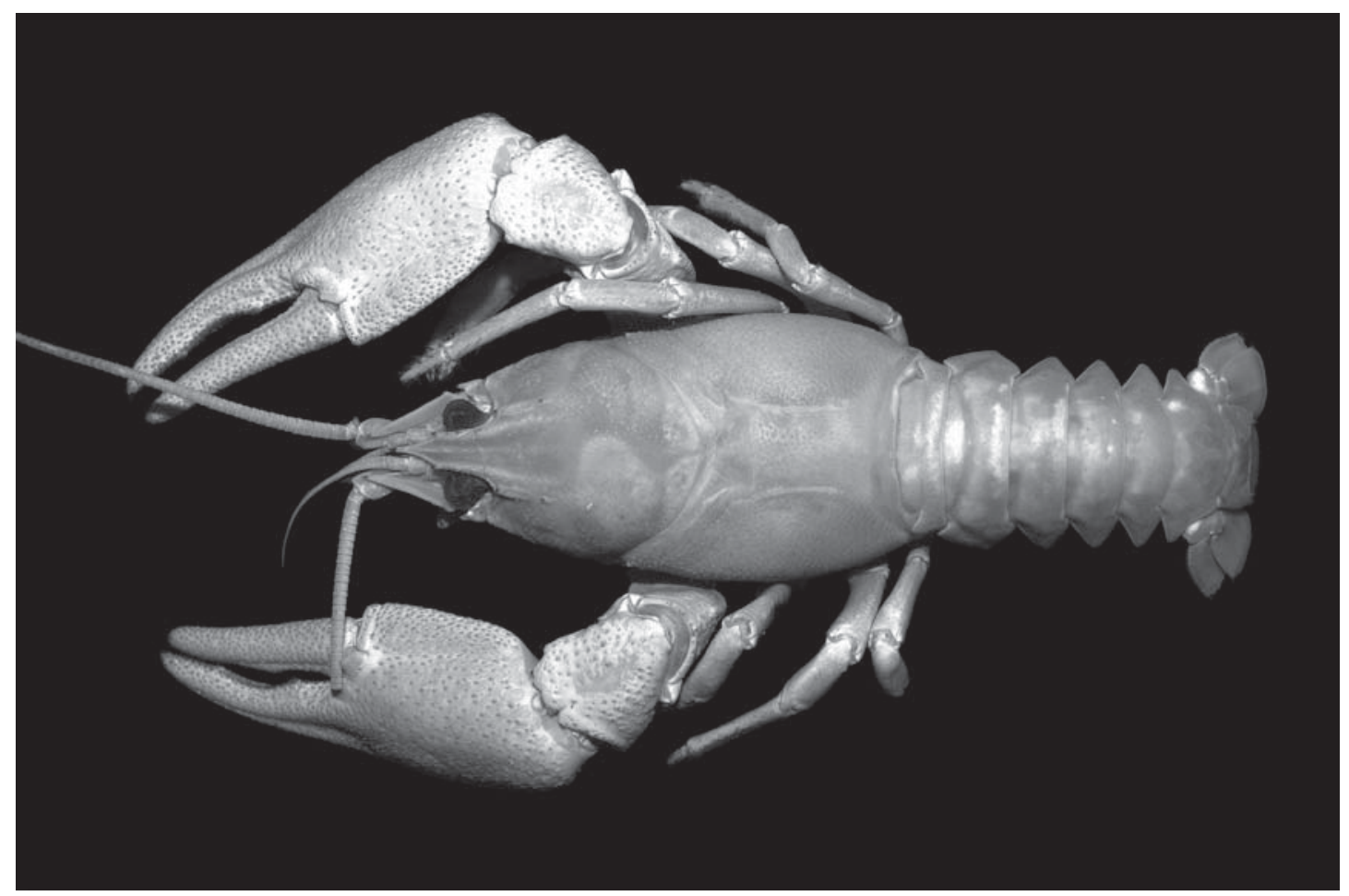

Fig. 2 Thick-clawed crayfish Astacus pachypus (ZIN RAS 87), Astrakhan, 1859, Academician Baer leg.

Рис. 2. Толстопалый рак Astacus pachypus (ЗИН РАН 87), Астрахань, 1859, собр. академик Бэр.

Potamogeton pectinatus). ... Numerous and various small animals, polyps, snail, worms, "crayfish" (or "crustacean"?) and insects live on the grass and between grass ... The bed of the estuary of River Chernaya is overgrown by dense cover of marine grass, while the river mouth is bordered by reed swamp ..." [Kessler, 1860]. Let us comment on this translation in a way that in the original Russian version Kessler used the word "pak", that most probably meant "crayfish". It could not be excluded, however that he used a broader meaning of this word capturing all higher crustaceans, such as amphipods and isopods.

In the beginning of XX century the bottom of the Lagoon of River Chernaya from the mouth of the river (Fig. 3,1 ) to the outmost large leg of the estuary (Fig. 3, 3) was still covered by eelgrass with a lower boundary at depth $6.5 \mathrm{~m}$. There were also oyster settlements and shelly substrates [Zernov, 1913]. This brackish environment with appropriate substrates could serve as an optimal habitat for A. pachypus. Taking into account a broad salinity tolerance of the crayfish and its occurrence in mineralized river water elsewhere, we can suppose its possible occurrence upstream of the river as well.

In the XX-th century this area experienced significant changes of hydrological regime owing to construction, re-construction and increasing capacity of the water intake station on the River Chernaya and the building of the breakwater at the exit from the bay. This along with eutrophication caused severe siltation throughout the entire Sevastopol Bay and vanishing of the eelgrass meadows [Shalovenkov, 2005].

To determine the current state of the potential habitat of $A$. pachypus near Sevastopol we surveyed the estuary and lower reaches of the Chernaya River to the lower end of Chernorechenskiy Canyon (Fig. 3, 1-7).

Examination of the River Chernaya estuary in $\mathrm{Au}-$ gust 2015 showed that the bottom is currently covered with a soft mud, releasing gases and contaminated with hydrogen sulfide. No indications of eelgrass growth was found. The water flow in the River Chernaya was very slow between the estuary (Fig. 3, 3) and the water intake station (Fig. 3, 5). Water characteristics there were the following:

- About $2 \mathrm{~km}$ upstream from the end of estuary (Fig. 3, 4): water mineralization $204 \mathrm{mg} / \mathrm{l}, \mathrm{pH}$ 6,9;

- below water intake station (Fig. 3, 5): water mineralization $200 \mathrm{mg} / \mathrm{l}, \mathrm{pH} 6,5$.

Search under stones, driftwood and setting of crayfish pots showed significant siltation of the bottom and did not indicated the presence of crayfish.

From Chernorechenskoe village (Fig. 3,6) to the lower end of the Chenorechenskiy Canyon (Fig. 3, 7) the river is full-flowing, the current is strong, especially on the rifts, but there is a large tranquil backwaters with macrophyte growth. The bottom is rocky, the water parameters are the following:

— near village Chernorechenskoe (Fig. 3, 6): water mineralization $199 \mathrm{mg} / \mathrm{l}, \mathrm{pH}$ 7,2;

- entrance of the Chenorechenskiy Canyon (Fig. 3, 7): water mineralization $194 \mathrm{mg} / \mathrm{l}, \mathrm{pH}$ 7,2. 


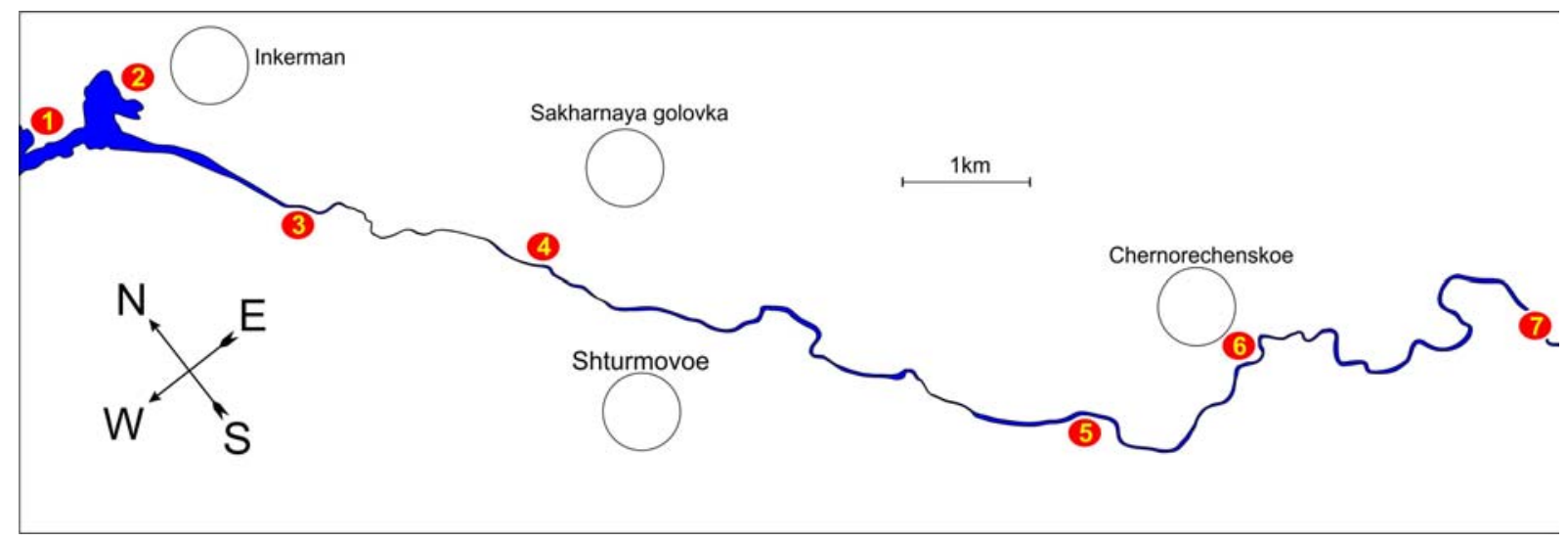

Fig. 3. Scheme of the lower stream and the estuary of Chernaya River: 1 - part of the estuary from the Lagoon of River Chernaya to Sevastopol Bay; 2 - Neftóanaya bay (Grafskaya); 3 - mouth of the River Chernaya; 4 - an intermediate part of research area; 5 - water intake station; 6 - Chernorechenskoe (Chorgun village); 7 - the lower end of Chernorechenskiy Canyon.

Рис. 3. Схема нижнего течения и эстуария р. Черная: 1 - часть эстуария от лагуны реки до внутренней части Севастопольской бухты; 2 - Нефтяная (Графская) бухта; 3 - устье реки Черная; 4 - промежуточная часть района исследований; 5 водозаборная станция; 6 - село Чернореченское (Чоргун); 7 - нижний предел Чернореченского каньона.

Search under stones, driftwood and setting of crayfish pots did not indicate the presence of crayfish.

Even though it is known that thick-clawed crayfish occurs usually in the lower stream of some rivers of the Black Sea - Azov Basin which have mineralized water, it is not particularly known which level of mineralization is preferable for the species. For example, near Starocherkassk on Don where the species is known to occur [Cherkashina et al., 1996] the water mineralization was $698 \mathrm{mg} / \mathrm{l}$ and $\mathrm{pH}$ amounted to 7.3 in August 2015 [Anosov, pers. observations]. It is about 3 times higher than in the River Chernaya near village Chernorechenskoe (Fig. 3, 6). If A. pachypus can tolerate such conditions, this part of the river with relatively intensive flow, moderate mineralization, $\mathrm{pH}$ slightly exceeding 7 , hard bottom, backwaters overgrown with macrophytes would be an appropriate habitat for the species. However this portion of the river has a limited spatial extent, less than $3 \mathrm{~km}$. The most important for the crayfish estuarine part of the river is now too swampy, has $\mathrm{pH}<7$ and shows consequences of long lasting eutrophication. The environmental conditions for thick-clawed crayfish there appear by far suboptimal. Therefore a local isolated population of $A$. pachypus having existed in the Sevastopol Bay and its watershed at least in the XIX century is nowadays most probably extinct. This fits in the general pattern of progressive shrinkage of the fragmented distribution range of the endangered crayfish species $A$. pachypus caused by habitat loss which continues in the decade scale.

ACKNOWLEDGEMENTS. This study was supported by the Russian Foundation for Basic Research (RFBR) Project No. 16-04-01526.

\section{References}

Birstein Ya.A., Vinogradov L.G. 1934. [Freshwater Decapoda of USSR and their geographical distribution] // Zoologicheskiy Zhurnal. Vol.13. Issue 1. P.39-70 [in Russian].
Bulgurkov K. 1964. [Astacus pachypus Rathke - new species of freshwater crayfish in the Bulgarian fauna] // Proceedings of the Institute of Fisheries. Vol. 5. P.122-123 [in Bulgarian].

Cherkashina N.Y. 1976. [Distribution and biology of thick-clawed crayfish (Astacus pachypus) in Turkmenian water of Caspian Sea] // Zoologicheslkiy Zhurnal. Vol.55. No.4. P.602-606 [in Russian].

Cherkashina N.Y., Tevyashova O.E., Karpenko V.N., Novikova E.C. 1996. [The status of populations crayfishes of genus Astacus in the reservoir of Azov-Don basin in the conditions of anthropogenic impact] // Sbornik nauchnyh trudov AzNIRKh. P.206-211 [in Russian].

Czerniavsky V. 1884. Crustacea Decapoda pontica littoralia. Charcovia: [University printing house]. 270 p., 7 Pls.

Gherardi F., Souty-Grosset C. 2010. Astacus pachypus. The IUCN Red List of Threatened Species. e.T153702A4533916. http:// dx.doi.org/10.2305/IUCN.UK.2010-3.RLTS.T1537 02A4533916. en. Downloaded on 07 February 2016.

Kessler K.F. 1860. [Zoological journey to the northern Balck Sea coast and to Crimea in 1858]. Kiev: Kiev Universiy Printing House. 246 p. [in Russian]

Kessler K.F. 1875. [Russian freshwater crayfish]. St. Petersburg. 94 p. [in Russian]

Mezhzherin S.V., Kostyuk V.S., Garbar V.S., Zhalai E.I., Kutishchev P.S. 2015. The thick-clawed crayfish, Astacus pachypus (Crustacea, Decapoda, Astacidae), in Ukraine: karyotype, allozymes and morphological parameters // Vestnik zoologii. Vol.49. No.1. P.41-48.

Rathke M.H. 1837. Zur Fauna der Krym. Ein Beitrag // Memoires Academie des Sciences St. Petersburg. Ser.6B. Bd.3. S.291-454.

Shalovenkov N. 2005. Restoration of some parameters in the development of benthos after reduction of anthropogenous loading in the ecosystem of the Sevastopol Bay in the Black Sea // Mitigation and Adaptation Strategies for Global Change. Vol.10. P.105-113.

Souty-Grosset C., Holdich D.M., No,1 P.Y., Reynolds J.D., Haffner P. 2006. Atlas of Crayfish in Europe. Paris: Muséum national d'Histoire naturelle. $187 \mathrm{p}$.

Zernov S.A. 1913. [On the study of life in the Black Sea] // Zapiski Imperatorskoi Akademii Nauk, St. Petersburg. Vol.32. No.1. P.3-241, 5 pls. [in Russian]

Responsible editor V.A. Spiridonov 